DOI: 10.17707/AgricultForest.61.3.13

\author{
Slađana GVOZDENOVIĆ, Milica MANDIĆ, \\ Dragana DRAKULOVIĆ, Aleksandar JOKSIMOVIĆ
}

\title{
THE SHELLFISH BIOTOXINS
}

\begin{abstract}
SUMMARY
Natural biotoxins (phycotoxins) are planktonic algae products which they produce to defence against predators. Bivalve shellfish can acummulate large quantities of biotoxins by water filtration. In humans these toxins can cause six syndromes: ASP, AZP, DSP, NSP, PSP and VSP. Detection of biotoxins is carried on HPLC (High- Performance Liquid Chromatography) with different detectors. In the coastal waters of Montenegro biotoxins monitoring started in 2014, but IMB working team performs regular monthly monitoring of toxic and potentially toxic algae species for years. In neighboring countries, primary Croatia, permanent marine biotoxins monitoring is performed per years as well as toxic algae species
\end{abstract}

Keywords: Biotoxins, shellfish, Boka Kotorska Bay, Montenegro

\section{INTRODUCTION}

Bivalve shellfish feed by filtrating large volumes of seawater. Microscopic planktonic algae of the world's oceans are critical food for filterfeeding bivalve shellfish (oysters, mussels, scallops, clams) as well as for the larvae of commercially important crustaceans and finfish. Shellfish through filtration process can accumulate pathogens and toxic substances such as natural biotoxins and heavy metals, so can causes danger for the whole food chain and in particular to human health. Biotoxins (phycotoxins) are planktonic algae products which they produce to defense against predators (FAO, 2004). The concentration of biotoxins in shellfish tissue is directly related to the abundance of toxic algae in the water (Huss et al., 2004), therefore shellfish usually accumulate biotoxins during algal bloom. First human DSP poisoning after consuming contaminated shellfish from the Adriatic Sea, has been recorded in 1989 (Boni et al., 1993; Čadež \& Teskeredžić, 2005).

Toxic algae mostly belong to dinoflagellates group (Taylor, 1976). In the Adriatic Sea, there are eighteen biotoxins produced dinoflagellates: Alexandrium minutum, A. tamarense, A. fundyense, A. lusitanicum, Dinophysis acuminata, D. acuta, D. caudata, D. fortii, D. norvegica, D. mitra, D. rotundata, D. sacculus, D. tripos, Prorocentrum micans, P. minimum, P. lima, Gymnodinium catenatum $i$ Lingulodinium polyedrum (Honsell, 1993). Of these species in the Boka Kotorska

\footnotetext{
${ }^{1}$ Slađana Gvozdenović, (corresponding author: sladjanag@ac.me), BIO-ICT Centre of Excellence in Bioinformatics, Cetinjska br. 2, 81000 Podgorica, MONTENEGRO, Milica Mandić, Dragana Drakulović, Aleksandar Joksimović, Institute of Marine Biology, Kotor, MONTENEGRO

Note: The authors declare that they have no conflicts of interest. Authorship Form signed online.
} 
Bay exsit six species: D. acuminata, D. acuta, D. caudata, D. fortii, P. micans and P. minimum (Drakulović, 2012; Drakulović et al., 2013) (Figure1-2). Biotoxins are also produced by diatoms as: Nitzschia navis-varingica, Pseudonitzschia australis, P. multiseries, P. seriata (Kotaki, 2008; Thessen, 2010) (Figure 3). In Boka Kotorska Bay live two genus from diatom group: Nitzschia spp. and Pseudo-nitzschia spp. (Drakulović, 2012). Recent studies in the Adriatic Sea have shown that the most frequent is dinoflagellate species, Dinophysis fortii that produce main toxin of DSP group (okadaic acid) is. Besides okadaic acid pecteno- and yessotoxins were also recorded (Ninčević-Gladan et al., 2011).
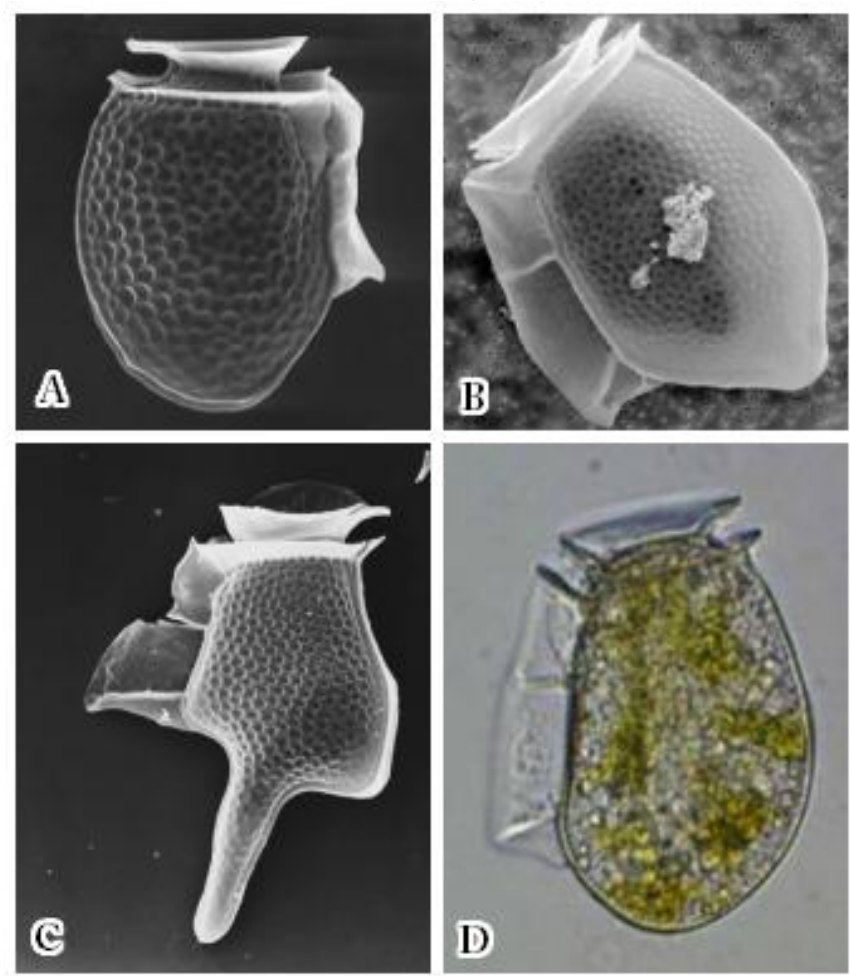

Figure 1. A) Dinophysis acuminata, B) D. acuta, C) D. caudata, D) D. fortii

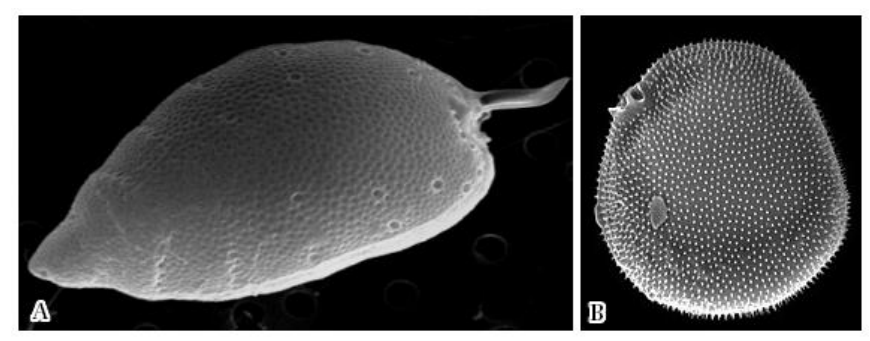

Figure 2. A) Prorocentrum micans, B) P. minimum 


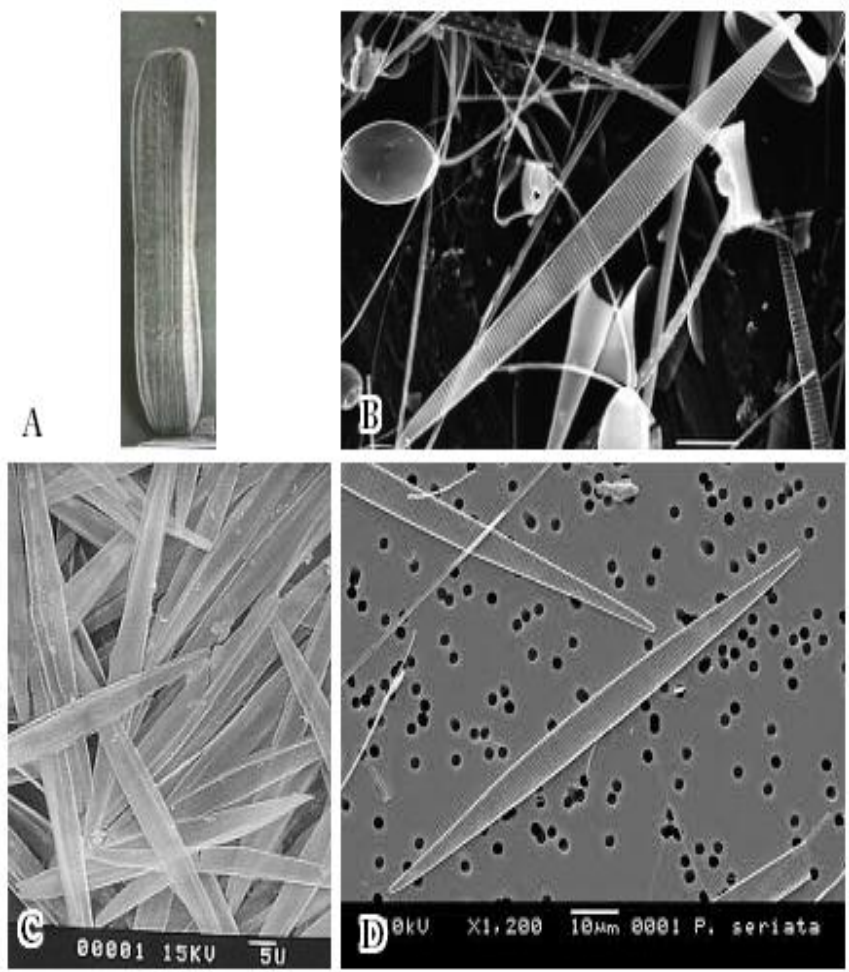

Figure 3. A) Nitzschia navis-varingica; B) Pseudo-nitzschia australis, C) P. multiseries, D) P. seriata

Depending on the type of poisoning biotoxins are separated into several groups:

-ASP - Amnestic Shellfish Poisoning;

-AZP - Azaspiracid Shellfish Poisoning;

-DSP - Diarrhetic Shellfish Poisoning;

-NSP - Neurotoxic Shellfish Poisoning;

-PSP - Paralytic Shellfish Poisoning;

-VSP - Venerupin Shellfish Poisoning.

\section{Amnestic Shellfish Poisoning}

This poisoning is caused by two species from diatoms genus, Nitzschia and Pseudo-nitzschia, which produce domoic acid. The highest accumulation of this toxin is in shells kidneys, gonads and digestive gland (FAO, 2004). Neuroexcitatory effect as interferes process of neurotransmission caused by domoic acid leads to damaged of neurons in the hypothalamus, which is responsible for memory process(Quilliam, 2003). Symptoms of poisoning in humans are: confusion, memory loss, nausea, headache, vomiting and occur within 24-48 hours after consummation of contaminated shellfish. The maximum allowable concentration of this toxin should not exceed $20 \mathrm{mg} / \mathrm{kg}$ shellfish meat 
(Regulation No. 853/2004). Detection of domoic acid can be done by liquid chromatography with ultra-violet detection (Quilliam et al., 1995).

\section{Azaspiracid Shellfish Poisoning}

This poisoning is caused by dinoflagellate species, Protoperidinium crassipes (James et al., 2003). Toxin that this species produce is called azaspiracid. It have been described that effects of azaspiracids could be related to cytoskeletal changes, such as E-cadherin degradation, caspase activation / apoptosis, membrane cholesterol reduction, or gene expression alterations (Vilarino, 2008). The highest content of this toxin is accumulation in digestive gland (James et al., 2008). In human body, this toxin spreading all over the body except the brain. Symptoms of poisoning in humans are: diarrhea, cramps, nausea and vomiting. Toxin also caused significant damage to the liver, pancreas, spleen as well as $\mathrm{T}$ and B lymphocytes. The maximum allowable concentration of this toxin should not exceed $160 \mu \mathrm{g} / \mathrm{kg}$ shellfish meat (Regulation No. 853/2004). Detection of azaspiracid can be done by analytical methods applying LC-MS/MS methods (James et al., 2003).

\section{Diarrhetic Shellfish Poisoning}

This poisoning is caused by species from two dinoflagellates genus, Dinophysis and Prorocentrum. Those algae species can produce three groups of toxins: okadaic acid and its derivatives, pectenotoxins and yessotoxins. Symptoms of poisoning in humans are gastrointestinal disturbances and appear one hour after shellfish consummation, and usually followed by mixed with bacterial infections. The highest accumulation of this toxins is in the fatty shellfish tissue (FAO, 2004). Some research suggest that okadaic acid can act a carcinogenic substance (Tubaro et al., 2008). The maximum allowable concentration of okadaic acid and pectenotoxins, together, should not exceed 160 $\mu \mathrm{g} / \mathrm{kg}$ shellfish meat (Regulation No. 853/2004). Humans poisoning by yessotoxins has never been reported, but because of lethal effect in mice, are considered as potentially dangerous (Ciminiello \& Fattorusso, 2008). Therefore, the maximum allowable concentrations of these toxin are $3,75 \mathrm{mg} / \mathrm{kg}$ shellfish meat (Regulation No. 786/2013). Detection of those toxins can be done by liquid chromatography (Yasumoto \& Murata, 1993).

\section{Neurotoxic Shellfish Poisoning}

This poisoning is caused by species from dinoflagellate group, Karenia brevis (Watkins et al., 2008). This species produced toxins belong to bravetoxins group, and its can form aerosol. Symptoms of poisoning (gasrointestinal and neurological) in humans appear 3-4 hours after consummation: nausea, vomiting, diarrhea, loss of taste, numbness of the lips and face, dilated pupils, alternating sensations of cold and heat. The maximum allowable concentrations of these toxins should not exceed $80 \mu \mathrm{g} / 100 \mathrm{~g}$ shellfish meat (Watkins et al., 2008). Detection of toxins can be done by liquid chromatography. 


\section{Paralytic Shellfish Poisoning}

This poisoning is caused by species from dinoflagellata group ( $A$. minutum, A. tamarensis, A.catanela and cyanobacteria (Anderson, 2000; FAO, 2004; Wiese et al., 2010). Produced toxins belong to saxitoxins group, and the highest content of these toxins are accumulate shells digestive system. The absorption of the toxin in humans is carried out quickly and spread across the whole body, including the brain. Symptoms of poisoning such as muscle numbness and paralysis appear thirty minutes after consummation and can lead to death due to suffocation. The maximum allowable concentrations of these

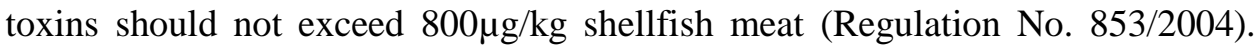
Detection of toxin can be done by liquid chromatography with fluorescence detection (Yakes et al., 2010).

\section{Venerupin Shellfish Poisoning}

This poisoning is caused by species from dinophlagellata group, $P$. minimum. Toxin which produce is venerupin. Algae bloom are often followed after heavy rains, increased amounts of phosphate, nitrate and ammonia in seawater (Sammy \& Satyanarayana, 1984). Symptoms of poisoning are: nausea, vomiting, stomach pain, tightness, headache, nausea, loss of appetite. Detection of toxin can be done by test on mices.

\section{BIOTOXINS IN THE COASTRAL WATERS OF MONTENEGRO}

In the coastal waters of Montenegro biotoxins monitoring started in 2014. Monitoring included shellfish farms in Boka Kotorska Bay by Centre for Ecotoxicological Tests (CETI). Institute for Marine Biology (IMB) conducts biotoxins monitoring in the framework of the Center of Excellence in Bioinformatics (BIO-ICT). Sampling began in November and will last for the next two years. Sampling is done on three farms in the bay as well as one point on the open sea. Monitoring covers the detection of ASP and PSP groups of toxins using a liquid chromatography. Sampling, transport, processing and preparation of solutions for liquid chromatography are made under the rules of the Community Reference Laboratory on Marine Biotoxins (http://aesan.msssi.gob.es/en/CRLMB/web/home.shtml). For detection of ASP toxins group protocol according Qualliam et al. (1995) is used, while for PSP toxins groups AOAC Official Method 2005.06 is used. IMB working team also performs regular monthly monitoring of phytoplankton community in the bay in order to monitor toxic and potentially toxic algae species. Due that biotoxins are dangerous supstances in humans, their control, especially on shellfish farms, is of great importance in terms of food safety.

Boka Kotorska Bay is quite isolated and closed basin with specific climatological, hydrological and hydrographic characteristics. By geographical and hydrographic characteristics the bay can be divided into three sections: Kotor-Risan bay, Tivat Bay and Herceg Novi Bay. Each part is characterized by a relatively large depth. The flow of fresh water from the atmosphere, land and 
marine resources is extremely large and as such have a positive influence on eutrophication reducing. The water flow is expressed mainly at depths up to $5 \mathrm{~m}$ and is most intense during maximum flow of fresh water. Managing the flow of current has output direction. Temperature, salinity and density of sea water are greatly influenced by hydro-meteorological parameters that are specific and subject to frequent local changes. Therefore, stratification of these parameters is not subject to the rules of the open sea.

There are sixteen shellfish farms in Boka Kotorska Bay, with a total annual production between 150-200 tonne. Mussels farming is done on a floating parks and breeding technology is reflected in two steps: adoption of acceptance spawn on collectors, sorting and seeding. Spawn younger adoption take about eight month. The seeding of mussels - first dressing, is best to be done in late September or March. After this step mussels spend 6-8 months in water. Individuals who are in the first finishing reached a length of about $4-5 \mathrm{~cm}$, are placed together and return to the water for next 6 months. After a total period, about 20 months, mussels reaches market size and can be placed on the market. Size of market mussels shall not be less than $5 \mathrm{~cm}$ (Anonymous, 2010). There are also fish farms in Montenegro: trout (annual production around 450 tonne), carp (annual production around 5 tonne), sea bream and sea grass (annual production around 50 tonne) (Mandic and Huter, 2014).

\section{BIOTOXINS IN THE REGION COASTRAL WATERS}

In neighboring countries, primary Croatia, permanent marine biotoxins monitoring is performed per years as well as toxic algae species. According to Regulation about hygiene of animal food origin, there are prescribed maximum permissible concentrations of biotoxins in live bivalve molluscs. These values are equivalent to the values recommended by the European regulations about hygiene rules for animal food origin (Regulation No. 853/2004).

According to the monitoring plan, there is weekly sampling of shells for detection of domoic acid, saxitoxins, DSP toxins as well as azaspiracids. If values of biotoxins are higher then it is permitted the obligation of laboratories are to inform responsible veterinary inspection, which will forward information to the farmers and bring a decision about banning the harvesting, collection and marketing of shellfish from that farm. After that sampling is done every fortyeight hours, until biotoxins values become below the permitted values. Closed farm may be opened only when two consecutive negative values.

Domoic acid has been recorded for first time in Croatia in January 2006 and it was preceded by blooms of algae from genus Pseudo-nitzschia. However, it was detected in low concentrations that were not harmful to human health (Ujević et al., 2010). A. minutum first recorded in 1992, while in the form of cysts found in 1989 (Čadež and Teskeredžić, 2005).

\section{CONCLUSIONS}

Although shellfish are healty food, because of potential presence of biotoxins can be threat to humans. Because of that, it is neccessery to introduce 
legislation about biotoxins control in shellfish meat. Based on knowledge about toxic algae species that present in the Boka Kotorska Bay, four types of poisoning can occure: amnestic poisoning, diarrhetic poisoning, paralytic poisoning and venerupin poisoning. Official data about poisoning in humans by biotoxins in Montenegro does not exist, but it is possible that some kinds of poisoning were mistaken with bacterial and viral infections due to the fact that the clinical picture of these disease are quite similar.

\section{ACKNOWLEDGMENTS}

This work has been supported by the Ministry of Science of Montenegro and HERIC project trough the BIO-ICT Centre of Excellence (Contract No. 011001).

\section{REFERENCES}

Anderson D. 2000. The Harmful algae page. www.redtide.whoi.edu/hab/.

Anonymous, Order prohibiting the hunting and the marketing of undersized fish, fry fish and other marine organisms, 2010.

Boni L, Milandri A, Poletti R, and Pompei M. 1993. DSP cases along the coasts of Emilia-Romagna (Northwestern Adriatic Sea). In: Smayda TJ, Shimizu Y. (ur.), Toxic Phytoplankton Blooms in the Sea. Elsevier, Amsterdam, 475-481.

Ciminiello P, Fattorusso E. 2008. Chemistry, metabolism, and chemical analysis. Seafood and Freshwater Toxins. CRC Press. Taylor \& Francis Group. Boca Raton. London. New York, 2008. 287-288.

Čadež V, Teskeredžić E. 2005. Patogeni mikroorganizmi i toksini koje prenose skoljkasi iz oneciscenih podrucja - zoonoze. Ribarstvo, 63(4): 135-145.

Drakulović D, 2012. Znacaj fitoplanktona kao indikatora eutrofikacije u akvatorijumu bokokotorskog zaliva. Doktorska disertacija, Univerzitet u Beogradu, Bioloski fakultet, pp. 227.

Drakulović D, Pestorić B, Joksimović D, Redzić A, Petović S, and Krivokapić S. 2013. Dinoflagellate assemblages in the Boka Kotorska bay. Studia Marina, 27(1): 65 84.

FAO 2004. FAO Food and nutrition paper 80. Marine biotoxins. Food and Agriculture Organization of the United Nations. Rome, 2004. 1, 2, 5, 14-18, 24, 25, 53, 66, 67, 71, 111, 137, 145-150, 173.

Honsell G. 1993. First report of Alexandrium minutum in Northen Adriatic waters (Mediterranean Sea). In: Dmayda TJ, Shmitzu Y. (ur.), Toxic phytoplankton blooms in the sea. Eslvier, Amsterdam, 127-132.

Huss HH, Ababouch L, and Gram L. 2004. Assessment and management of seafood safety and quality. Food and Agriculture Organization of the United Nations. Rome, pp. 444.

James KJ, Moroney C, Roden C, Satake M, Yasumoto T, Lehane M, and Furey A. 2003. Ubiquitus „benign" alga emerges as the cause of shellfish contamination resposible for the human syndrome, azaspiracid poisoning. Toxicon, 43: 143-151.

James KJ, Fernandez G, Furey A, and O'driscoll A. 2008. Azaspiracids: chemistry, bioconversion, and determination. Seafood and Freshwater Toxins. CRC Press. Taylor \& Francis Group. Boca Raton, London. New York, 767-768. 
Kotaki Y. 2008. Ecobiology of amnesic shellfish toxin producing diatoms. Seafood and freshwater toxins. CRC Press. Taylor \& Francis Group. Boca Raton, London. New York, pp. 383.

Mandić M, Huter A. 2014. Projekat o tehničko-tehnološkim uslovima komercijalnog uzgoja Kamenice (Ostrea edulis) i Dagnje (Mitylus galloprovincialis) u ekološkim uslovima Risanskog zaliva. Područje - Sektor 8 (Turski rt - Kostanjica - Donji Morinj). Univerzitet Crne Gore, Institut za Biologiju Mora Kotor, pp. 54.

Ninčević Gladan Z, Ujević I, Milandri A, Marasovic I, Ceredi A, Pigozzi S, Arapov J, and Skejic S. 2011. Lipophilic toxin profile in Mytilus galloprovincialis during episodes of diarrhetic shellfish poisoning (DSP) in the N.E. Adriatic sea in 2006. Molecules, 16: 888-899.

Quilliam MA, Xie M, and Hardstaff WR. 1995. Rapid extraction and cleanup for liquid chromatographic determination of domoic acid in unsalted seafood. J AOAC Int., 78: 543-554.

Quilliam MA. 2003. Chemical methods for domoic acid, the amnestic shellfish poisoning (ASP). Manual on harmful marine microalgae. Monographs on Oceanographic Methodology, 11(9): 247-266.

Regulation (EC) No 853/2004 of the European Parliament and of the Council of 29 April 2004 laying down specific hygiene rules for food of anumal origin (Official Journal of the European Union L 139 of 30 April 2004), pp. 8.

Regulation (EU) No 786/2013 of 16 August 2013 amending Annex III to Regulation (EC) No 853/2004 of the European Parliament and of the Council as regards the permitted limits of yessotoxins in live bivalve molluscs.

Sammy MR, and Satyanarayana RK, 1984. Manual on marine toxins in bivalve molluscs and general consideration of shellfish sanitation. CMFRI Special Publication, 16:104.

Taylor FJR. 1976. Dinoflagellates from the International Indian Ocean Expedition. Biblioteca Botanica, 132: 1-234.

Thessen A. 2010. Pseudo-nitzschia. http://diatoms.lifedesks.org/pages/990.

Tubaro A, Bornancin A, Hungerford J, and Sosa S. 2008. Pharmacology and toxicology of diarrheic shellfish toxins. Seafood and Freshwater toxins. CRC Press. Taylor \& Francis Group. Boca Raton. London. New York, 231-239.

Ujević I, Ninčević-Gladan Ž, Roje R, Skejić S, Arapov J, and Marasović I. 2010. Domoic acid - a new toxin in the croatian Adriatic shellfish toxin profile. Molecules, 15(10): 6835-6849.

Vilarino N. 2008. Marine toxins and cytoskeleton: azaspiracids. FEBS Journal, 275: 6075-6081.

Watkins SM, Fleming LE, Hammond R, and Reich A. 2008. Neurotoxic shellfish poisoning. Marine Drugs, 6: 431-455.

Wiese MP, D’Agostino M, Mihali TK, Moffitt MC, Neilan BA. 2010. Neurotoxic alkaloids: Saxitoxin and its analogs. Marine Drugs, 8: 2185-2211.

Yakes BJ, Campbell K, Elliot CT, Degrasse SL, Haughey SA, and Prezioso S. 2010. An improved immunoassay for detection of saxitoxin by surface plasmon resonance biosensors. Sensors and Actuators B: Chemical, 156: 805-806.

Yasumoto T, Murata M, 1993. Marine toxins. Chemical Reviews, 93: 1897-1909. 